\title{
Predictive Nonlinear PID Neural Voltage-Tracking Controller Design for Fuel Cell based on Optimization Algorithm
}

\author{
Essra A. Jaber ${ }^{1}$, Ahmed S. Al-Araj ${ }^{2}$, Hayder A. Dhahad ${ }^{3}$ \\ ${ }^{1}$ Control and Systems Engineering Department, University of Technology, Baghdad-Iraq \\ ${ }^{2}$ Computer Engineering Department, University of Technology, Baghdad, Iraq \\ ${ }^{3}$ Mechanical Engineering Department, University of Technology, Baghdad-Iraq \\ esraabbas599@gmail.com,60166@uotechnology.edu.iq,hayder_abed2002@yahoo.com
}

\begin{abstract}
This paper proposes a predictive nonlinear PID neural voltagetracking controller design for Proton Exchange Membrane Fuel Cell (PEMFC) Model with an on-line auto-tuning intelligent algorithm. The purpose of the proposed robust feedback nonlinear PID neural predictive voltage controller is to find the optimal value of the hydrogen partial pressure action in order to control the stack terminal voltage of the (PEMFC) model for one-step-ahead prediction. The Chaotic Particle Swarm Optimization (CPSO) is utilized as a stable and intelligent robust on-line auto-tuning algorithm to obtain the nearoptimal weights for the proposed controller so as to improve the performance index of the system as well as to minimize the energy consumption. The Simulation results demonstrated the effectiveness of the proposed controller compared with the linear PID neural controller.
\end{abstract}

\section{Index Terms - Chaotic Particle Swarm Optimization, Fuel Cell, Nonlinear PID Neural Controller.}

\section{INTRODUCTION}

In recent years, fuel cells have been widely used due to their electrochemical nature, where the fuel cells generate the electric power as a result of a chemical reaction in which oxygen and hydrogen are used. Fuel cells get their chemical compounds to interact from nature, and this distinguishes them from other sources of the electricity power generation (such as batteries and internal combustion engines). In addition, there are many advantages of fuel cells such as; they are considered as a clean source of energy, they cause less emission, which approaches to zero, and they work quietly. The fuel cells are made up from two sides, the left side and the right side, where the left side is the entrance to the hydrogen gas known as the anode side and the other side is known as the cathode, which is an input of the oxygen gas. These sides are known as electrodes. The other content of fuel cells is the electrolyte. The catalyst material covers the electrodes [1]. The power generated from each single cell is less or equal to one volt; therefore, a group of cells is connected either sequentially or in a parallel form to generate the required power, and in this case, the group of fuel cells is called the stack. According to the type of electrolyte, the fuel cells are classified into many types such as: direct methanol fuel cell, alkaline fuel cell, phosphoric acid fuel cells, molten carbonate fuel cell, solid oxide fuel cell, reversible fuel cell and proton exchange membrane fuel cells [2]. The PEMFC is very interesting because it has many qualifications such as, the PEMFC can be operated at room temperature, it requires low pressures, and it has speedy start-up, quiet operation, small size and high efficiency [3], [4]. There are many factors that affect the work of fuel cells in the production of electric power. Therefore, in order to ensure the generation of the greatest energy, several researchers suggested various control methods to track the 
output voltage of the fuel cell stack when the load current is variable, including fuzzy logic controller [5], optimal PEMFC based hybrid learning [6], cascade control [7], robust neural network adaptive control [8], support vector machine (SVM) [9], traditional sliding mode controller [10], hybrid Taguchi method and genetic algorithm neural networks [11], backtracking search algorithm combined with Burger's chaotic map (BSABCM) [12], second order sliding mode [13], etc. To understand the implicated phenomena of fuel cells, many kinds of intelligent algorithms are used, such as Salp Swarm Optimizer (SSO) [14], particle swarm optimization [15], genetic algorithm [16], Bio-Inspired Proton Systems based Optimization Algorithm (BIPOA) [17], and grey wolf optimization [18].

The motivation of this paper is to focus on the dynamic response of the PEM fuel cell stack and to stabilize the power output, especially when it uses different loads in mobile applications. Furthermore, the modeling representation of the PEMFC system and controlling the output voltage are still challenging issues.

The main contributions of this paper are to:

- Study and analyze the PEM fuel cell operating system in terms of the effect of each variable inputoutput such as hydrogen partial pressure, temperature and load current.

- Design of a feedback nonlinear PID neural controller with a prediction algorithm for one-step ahead to stabilize and track the desired output voltage of the fuel cell system in the transient state as well as to get the optimal or near optimal value of the hydrogen partial pressure control effort.

- Improve and stabilize the output voltage performance of the PEMFC system using an on-line performance index evaluation.

This paper is arranged as follows: Section 2 explains the modeling of the PEMFC system. Section 3 illustrates the predictive nonlinear PID neural network controller. Section 4 discusses the numerical results of the simulation for the proposed controller. Section 5 gives the conclusions of the proposed controller.

\section{MODELING OF THE PEM FUEL CELLS}

Due to the important role of fuel cells in many applications, they must be manufactured carefully. Hence, this type of fuel cells is considered expensive because both the membrane and the electrode are made up from platinum [6]. This type of fuel cells is one of the important and eco-friendly sources of future power generation [6]. The main operation concept for this type of fuel cells can be explained as illustrated in Fig. 1. In particular, when the $\mathrm{H}_{2}$ gas inters the PEM fuel cell from the left side, which is called the anode, it decays into two compounds, namely positive chemical compounds, which are called the protons, and negative chemical compounds, which are called the electrons, because of the presence of the platinum catalyst. Only the positive compounds pass from the left to the right side [6], [18].

The chemical reaction at the left side is given by:

$$
2 \mathrm{H}_{2} \rightarrow 4 H^{+}+4 e^{-}
$$

Negative chemical compounds (electrons) transport through the external electrical circuit to generate the electric signal. Positive and negative compounds react with oxygen from the air to produce water and energy as a result of the chemical reaction [6], [8].

The chemical reaction at the right side is given by:

$$
4 e^{-}+4 \mathrm{H}^{+}+\mathrm{O}_{2} \rightarrow 2 \mathrm{H}_{2} \mathrm{O}
$$

The water produced by the chemical reaction must be managed in such a way that maintains the PEMFC, where the water pool on the cathode side leads to cell flooding and cell loss [3].

Each single cell produces an energy ranging from 0.9 to 1 volts. These are few volts to operate any system. Therefore, to find a solution for this problem, several studies have proposed linking cells 
in a parallel or sequential group, and hence, the new name for this group is the stack. The operating temperature of this type of cells is around $\left(50\right.$ to $\left.80 \mathrm{C}^{\circ}\right)$ [5], [6], [8]. For the purpose of modeling the system controllers and simulating the power state, the modules use a polarization curve that shows the relationship between voltage and current (V-I).

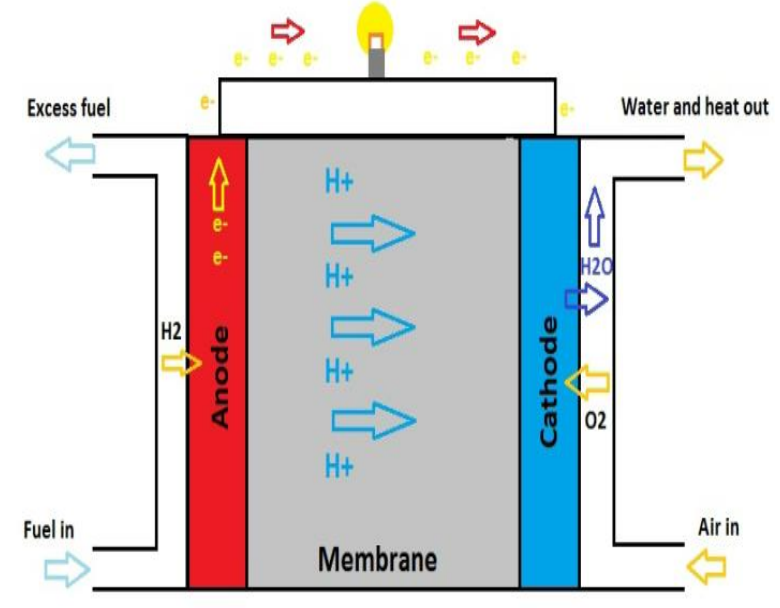

FIG. 1. THE MAIN CONCEPT OF THE PEMFC WORK [18].

The mathematical model of the PEMFC can be calculated by using the equations below [6], [8], [18].

$$
\begin{gathered}
\mathrm{V}_{\text {cell }}=\mathrm{V}_{\text {steady }}-\mathrm{V}_{\text {transient }} \\
\mathrm{V}_{\text {steady }}=\mathrm{E}_{\mathrm{N}}-\mathrm{V}_{\text {ohm }} \\
\mathrm{V}_{\text {transient }}=\mathrm{V}_{\text {act }}+\mathrm{V}_{\text {con }}
\end{gathered}
$$

Where: $\mathrm{V}_{\text {cell }}$ represents the output voltage of the fuel cell in volt.

$\mathrm{E}_{\mathrm{N}}$ : represents the thermodynamic potential in volt.

$V_{\text {act: }}$ is a low voltage due to the interaction between the anode and the cathode (volt).

$\mathrm{V}_{\text {con }}$ : is the concentration overvoltage in volt.

$\mathrm{V}_{\text {ohm: }}$ : represents the voltage decline resulted from the impedance of the conduction of protons through the electrolyte and of the electrons through their path in volt.

The important characteristics of the PEMFC are taken from [19], and they are explained in Table I.

TABLE I. THE CHARACTERISTICS OF PEMFC [19].

\begin{tabular}{lll}
\hline Parameters & Values & Units \\
\hline $\mathrm{N}_{\text {cell }}$ & 32 & -- \\
$\mathrm{T}$ & 298 & Kelvin degree \\
$\mathrm{A}$ & 64 & $\mathrm{~cm}^{2}$ \\
$\mathrm{~L}$ & $178 \times 10^{-6}$ & $\mathrm{~cm}$ \\
$\mathrm{PH}_{2}$ & $1-5$ & Atm \\
$\mathrm{PO}_{2}$ & 0.2 & Atm \\
$\mathrm{R}_{\mathrm{c}}$ & 0.0003 & $\Omega$ \\
$B$ & 0.0169 & $\mathrm{~V}$ \\
$\alpha_{1}$ & 0.948 & -- \\
$\alpha_{2}$ & -0.00312 & -- \\
$\alpha_{3}$ & $-7.6 \times 10^{-5}$ & -- \\
$\alpha_{4}$ & $1.93 \times 10^{-4}$ & \\
$\mathrm{~J}$ & 0.0073 & $\mathrm{~mA} / \mathrm{cm}^{2}$ \\
$\mathrm{~J}_{\max }$ & 0.469 & $\mathrm{~mA} / \mathrm{cm}^{2}$ \\
$\Phi$ & 23 & -- \\
\hline
\end{tabular}

Received 8 May 2019; Accepted 5 September 2019 
The thermodynamic potential $\left(\mathrm{E}_{\mathrm{N}}\right)$ can be calculated by using the equation below [19]:

$E_{N}=1.229-0.85 \times 10^{-3} \times(T-298)+4.3085 \times 10^{-5} \times T \times\left(\left(\ln P H_{2}\right)+0.5 \times \ln \left(P_{2}\right)\right)$

Where $\mathrm{PH}_{2}$ is the partial pressure of hydrogen in bar and $\mathrm{PO}_{2}$ is the partial pressure of oxygen in bar.

Activation loss is the voltage falling because of the activity between the anode and the cathode [19]. This type of losses can be calculated as shown below:

$$
V_{\text {act }}=\alpha_{1}+\alpha_{2} \times T+\alpha_{3} \times T \times \ln \left(\mathrm{CO}_{2}\right)+\alpha_{4} \times T \times \ln (I)
$$

Where,

I is the load current in Amper.

$\mathrm{CO}_{2}$ is the oxygen concentration dissolved in the surface of the cathode $\left(\mathrm{ohm} / \mathrm{cm}^{3}\right)$.

$\mathrm{CO}_{2}$ can be calculated using the Henry law, as shown in the equation below [19].

$$
\mathrm{CO}_{2}=\frac{\mathrm{PO}_{2}}{5.08 * 10^{6} \times \exp \left(\frac{-498}{T}\right)}
$$

The voltage of the ohmic loss can be determined by using the equation below [19], [20].

$$
V_{\text {ohm }}=I \times\left(R_{c}+R_{m}\right)
$$

Where,

$R_{m}$ represents the equivalent resistance of the electron flow in ohm and $R_{c}$ represents the constant value of the proton resistance in ohm.

$$
R_{m}=\frac{\rho_{m} L}{A}
$$

Where, $\rho_{\mathrm{m}}$ is the specific resistance of the membrane, and it can be calculated using the equation below:

$$
\rho_{m}=\frac{181.6\left[1+0.03\left(\frac{I}{A}\right)+0.062\left(\frac{T}{303}\right)^{2} \times\left(\frac{I}{A}\right)^{2.5}\right.}{\Phi-0.634-3\left(\frac{I}{A}\right) \exp \left[\frac{4.18(T-303)}{T}\right]}
$$

The concentration loss can be determined utilizing the equation below [19], [20].

$$
V_{\text {con }}=-\beta \times \ln \left(1-\frac{J}{J \max }\right)
$$

Where, $\beta$ represents the cell type dependence parameter.

$\mathrm{J}$ represents the density of the current that passes through the cell (Amper $\left./ \mathrm{m}^{2}\right)$.

Jmax explains the maximum current density that passes through the cell [19], [20], where

$$
J_{\max }=\frac{\operatorname{Imax}}{A}
$$

The total output voltage of the stack can be determined by the equation below [19], [20].

$$
V_{F C}=N_{\text {cell }} \times V_{\text {cell }}
$$

Where, Ncell symbolizes the number of stack.

The equation below is used to determine the overall output power (in watt) from the stack:

$$
\text { Power }_{F C}=I V_{F C}
$$




\section{THE PREDICTIVE PID NEURAL CONTROLLER DESIGN}

The controller proposed in this paper is a combination of the predictive nonlinear neural network with the PID controller, where the traditional PID control module is characterized by simplicity, efficiency, but the traditional PID control can not be used in multi-input multi-output nonlinear system, since this controller with self-tuning parameter techniques is necessary to use such systems to overcome external disturbances and parameter variations that are impredictable and can not be accurately modelled. On the other hand, neural networks require a large training time and a large number of parameter settings [21], [22]. This type of control, which combines the features of the PID and the Neural Network, leads to high performance and provides strong and adaptive controller. Fig 2 explains the main structure of the predictive nonlinear PID neural network. The structure of the nonlinear PID neural network consists of two parts, the first part explains tha Nonlinear PID Neural Nerwork (NPIDNN) and the second part explains the on-line tuning algorithm. Based on the characteristics of the PEMFC system operation, there are three outputs of the PEMFC system, namely the Fuel-Cell stack output voltage (VFC), the temperature (T), and the load current $\left(\mathrm{I}_{\mathrm{L}}\right)$, while the inputs of the PEMFC system, which control the operation of the Fuel Cell, include the hydrogen partial pressure $\left(\mathrm{PH}_{2}\right)$ controlled effort and the oxygen partial pressure $\left(\mathrm{PO}_{2}\right)$, which is considered as a constant value in this proposed work.

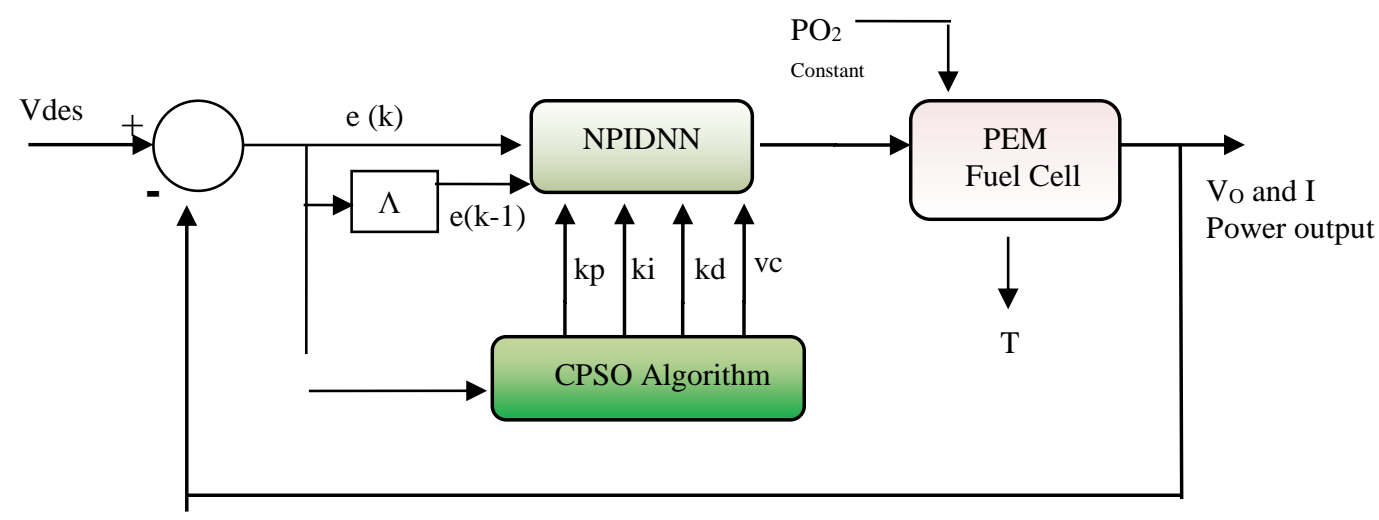

FIG. 2. THE STRUCTURE OF THE PROPOSED PREDICTIVE NONLINEAR PID NEURAL NETWORK.

\section{A. Predictive Nonlinear PID Neural Network (NPIDNN) Controller Structure}

Fig 3 explains the construction of the predictive nonlinear PID neural network controller for the PEM fuel cell.

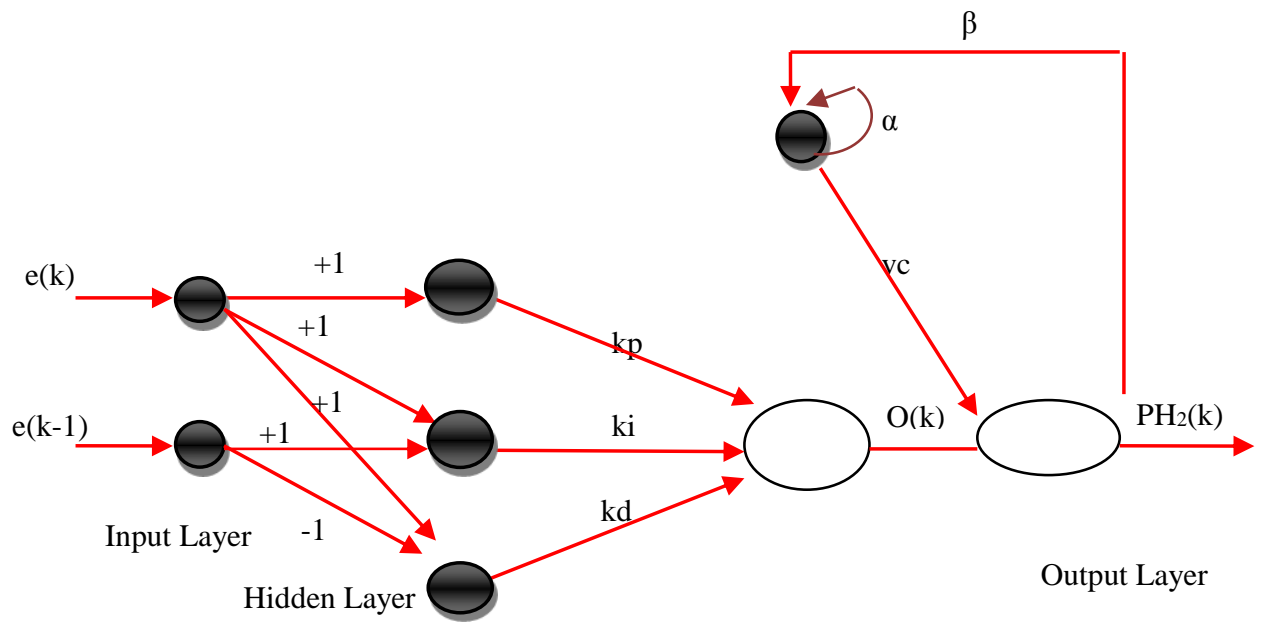


The above structure represents a multi-layer recurrent neural network, which consists of three layers. The input layer consists of $(\mathrm{e}(\mathrm{k})$ and $\mathrm{e}(\mathrm{k}-1))$. The number of neurons in the hidden layer is three representing the proportional, integral, and differential neurons. After $\mathrm{kp}$, ki, and $\mathrm{kd}$ gains are calculated, they are passed to the output layer. The output layer uses a sigmoid function to calculat the weighted sum (representing the output of the hidden layer), as follows:

$$
\begin{gathered}
n e t(k)=k_{p} \times e(k)+k_{i} \times(e(k)+e(k-1))+k_{d} \times(e(k)-e(k-1)) \\
O(k)=\frac{1}{1+\exp ^{(-1 \times n e t(k))}}
\end{gathered}
$$

Where, $\mathrm{kp}, \mathrm{ki}$, and $\mathrm{kd}$ are the proportinal, integral, and derivative gains, respectively.

$\mathrm{e}(\mathrm{k})$ is the tracking error defined as the diffrence between the desired output voltage $\left(\mathrm{V}_{\mathrm{des}}\right)$ and the actual output voltage (Vo).

The general equation of the predective nonlinear PID neural network controller is:

$$
\mathrm{PH}_{2}(k)=O(k)+v c \times h c(k-1)
$$

Where,

$\mathrm{PH}_{2}(\mathrm{k})$ represents the control effort for one step ahead.

$\mathrm{vc}$ is the adjustable weight from the PSO algorithm.

$$
h c(k)=\beta \times P H_{2}(k-1)+\alpha \times h c(k-1)
$$

$\alpha$ and $\beta$ are gains whose values are proposed to be 0.1 , and hc represents a variable.

The learning algorithm is usually based on the minimization (with respect to the network weights) of the following objective cost function, as in the equation below:

$$
\left.E=\frac{1}{P} \sum_{i=1}^{p}(e(k+1))^{2}=\frac{1}{P} \sum_{i=1}^{p} \operatorname{Vdes}(k+1)-V o(k+1)\right)^{2}
$$

Where, $P$ represents the number of training points in the training set, $\mathrm{k}$ presents the sample number, $\mathrm{i}$ presents the iteration acount, $\mathrm{e}(\mathrm{k}+1)$ denotes the prediction model error at each iteration among the true voltage output of the PEMFC and the desired output voltage, Vo is the actual output voltage of the fuel cell of each iteration, and Vdes represents the desired output voltage at each iteration.

\section{B. The On-Line Auto-Tuning Intelligent Algorithm}

The Particale Swarm Optimization (PSO) is used as one of the modern stochastic search and intelligent algorithms to train the nonlinear PID neural network. The PSO algorithm is famous for providing solutions for many difficult optimization problems due to its powerful search capabilities, quick convergence, and easy implementation. The PSO goal is to find and tune the best weights ( $\mathrm{kp}$, $\mathrm{ki}, \mathrm{kd}$ and $\mathrm{vc}$ ) of the PID neural network. In addition, to show the effectiveness in terms of number of iterations for evaluating the objective cost function and the minimum value obtained for the mean square error cost function, Equation (20) is used. However, this algorithm becomes ineffective for two reasons; when there are many local optimum and because of the random nature of the particle generation, the algorithm takes a long time to come close to the optimal solution. To solve this problem, the PSO is hybridized with the chaos method to produce a new algorithm (CPSO), and this algorithm has the ability to approach the optimal solution in less number of iterations. Therefore, the CPSO is used to train the predictive nonlinear PID neural network.

The steps of the CPSO can be explained as follows: 
The first step: Define the PEMFC parameters such as the hydrogen partial pressure $\left(\mathrm{PH}_{2}\right)$, the oxygen partial pressure $\left(\mathrm{PO}_{2}\right)$, the temperature $(\mathrm{T})$, the number of cells $\left(\mathrm{N}_{\text {cell }}\right)$, the maximum current $\left(\mathrm{I}_{\max }\right)$, and the current of the cell $\left(\mathrm{I}_{\text {cell }}\right)$.

The second step: Adjust the maximum iteration number and initialize particles (kp, ki, kd and vc) randomly.

The third step: Test the activation for each particle.

Based on the PSO procedure, the performance mainly depends on its parameters, and it often leads to be trapped in local optimum, in this state the partical is called active. But in other states the partical is not be trapped in the local optimum and the speed of the particale is equal to zero, the partical in this state is called inactive.

If the particle is active:

1) Evaluate the cost function using the mean square error, as shown in equation (20) above.

2) Update the velocity and position for each particle using the two equations below [23]:

$$
\begin{gathered}
v_{i}(k+1)=w \cdot v_{i}(k)+c_{1} r_{1}\left[L_{\text {best }-i}-x_{i}(k)\right]+c_{2} r_{2}\left[G_{\text {best }}-x_{i}(k)\right] \\
x_{i}(k+1)=x_{i}(k)+v_{i}(k+1)
\end{gathered}
$$

Where, $c_{1}$ and $c_{2}$ are cognitive coefficients, and $\mathrm{r}_{1}$ and $\mathrm{r}_{2}$ are two uniform random numbers.

Else the particle is inactive:

The CPSO algorithm works as follows:

1) Estimate the Logistic equation to find $W_{\text {new }}[23]$, [24].

$$
\beta(k+1)=\mu \beta(k)[1-\beta(k)]
$$

Where, $\mu$ is equal to 4 as the control parameter therefore, $(0) \notin\{0,0.25,0.5,0.75,1\}$.

$$
\begin{gathered}
\mathrm{w}(\mathrm{k})=\mathrm{w}_{\max }-\left[\left(\mathrm{w}_{\max }-\mathrm{w}_{\min }\right) \times \frac{\text { iteration }}{\text { max.no.iteration }}\right] \\
w_{\text {new }}=\beta(k+1) w
\end{gathered}
$$

2) Find a better performance index (mean square error)

3) Update the particles using the equations below [23], [24].

$$
\begin{gathered}
v_{i}(k+1)=w_{\text {new }} \cdot v_{i}(k)+c_{1} r_{1}\left[L_{\text {best }-i}-x_{i}(k)\right]+c_{2} r_{2}\left[G_{\text {best }}-x_{i}(k)\right] \\
x_{i}(k+1)=x_{i}(k)+v_{i}(k+1)
\end{gathered}
$$

The forth step: Update the iteration counter. If one of the stopping criteria is satisfied, then stop, else loop to the first step.

Fig 4 depicts a flowchart of the CPSO algorithm. After each sampling time, the weights of the online nonlinear PID neural network are updated to minimize the error between the actual output of the PEMFC model and the desired voltage. 


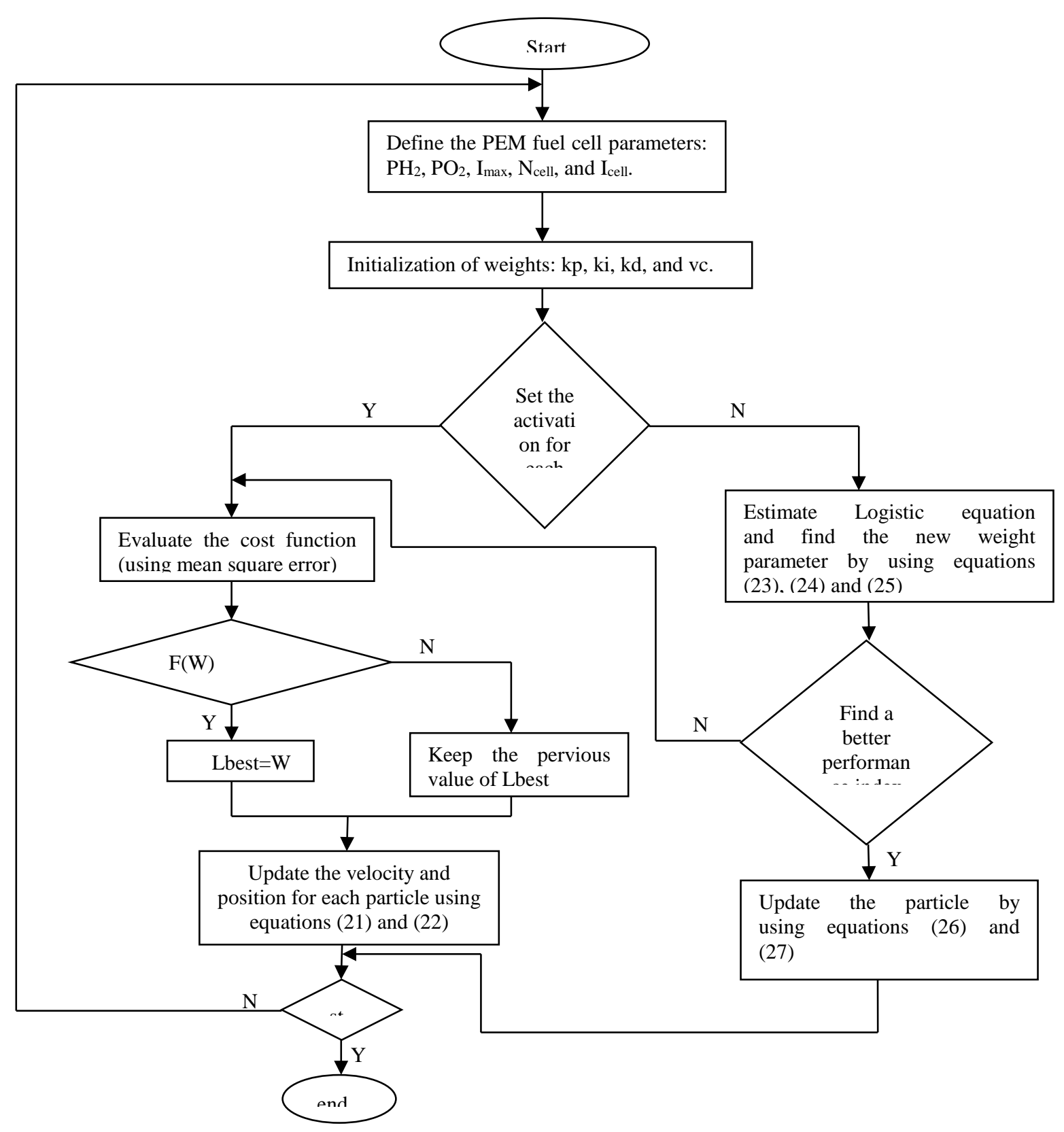

FIG. 4. A FLOWCHART OF THE CPSO ALGORITHM.

\section{NUMERICAL SIMULATION RESULTS}

The suggested form of the predictive nonlinear PID neural network controller, as explained in Fig. 2 , is carried out by using the MATLAB m.file (2018) package. The first stage in the controller design is necessary to study and analyze the dynamic characteristics of the PEMFC system that has the physical parameters shown in Table I. The first study is to show the polarization curve of the output voltage and the stack output power of the Fuel Cell in the normal operation state during changine the load current from $0 \mathrm{~A}$ to $30 \mathrm{~A}$, while the hydrogen partial pressure is at a constant value of $1.0 \mathrm{bar}$, the oxygen partial pressure is at a constant value of 0.2 bar and the temperature of the operation is constant at $25 \mathrm{C}^{\circ}$, as shown in Fig. (5, a and b). The maximum power of this model is clearly at the current which is equal to 29 A. Fig 6 shows the polarization curve of the loss voltage in the Fuel Cell system during changing the load current from 0 A to $30 \mathrm{~A}$. 


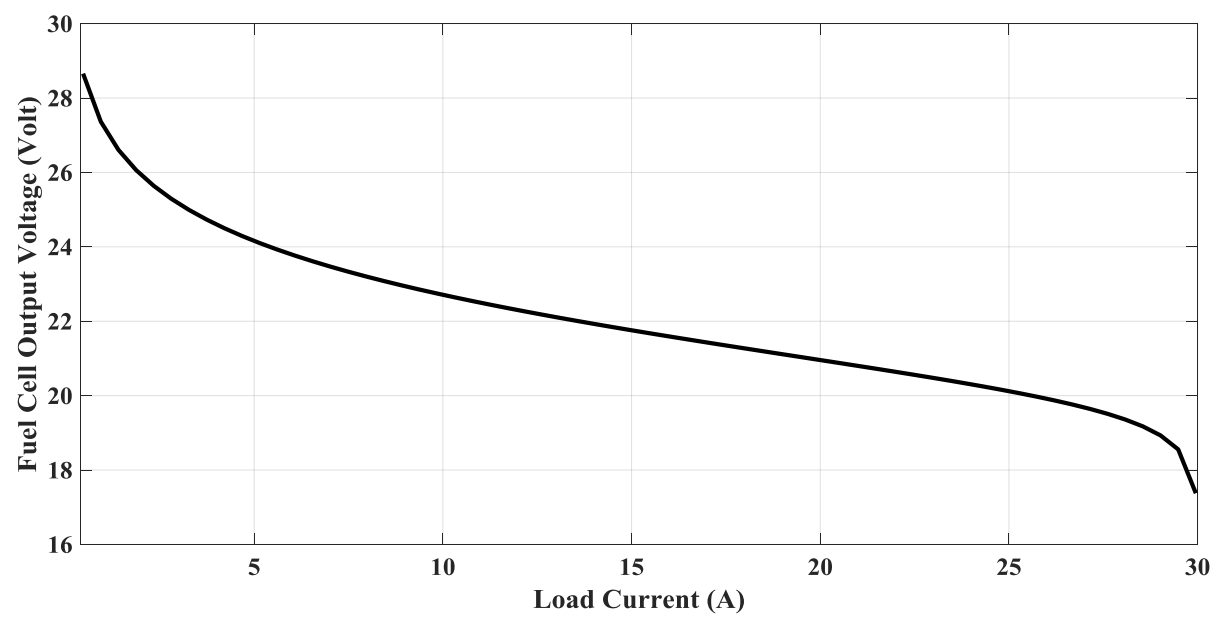

(a)

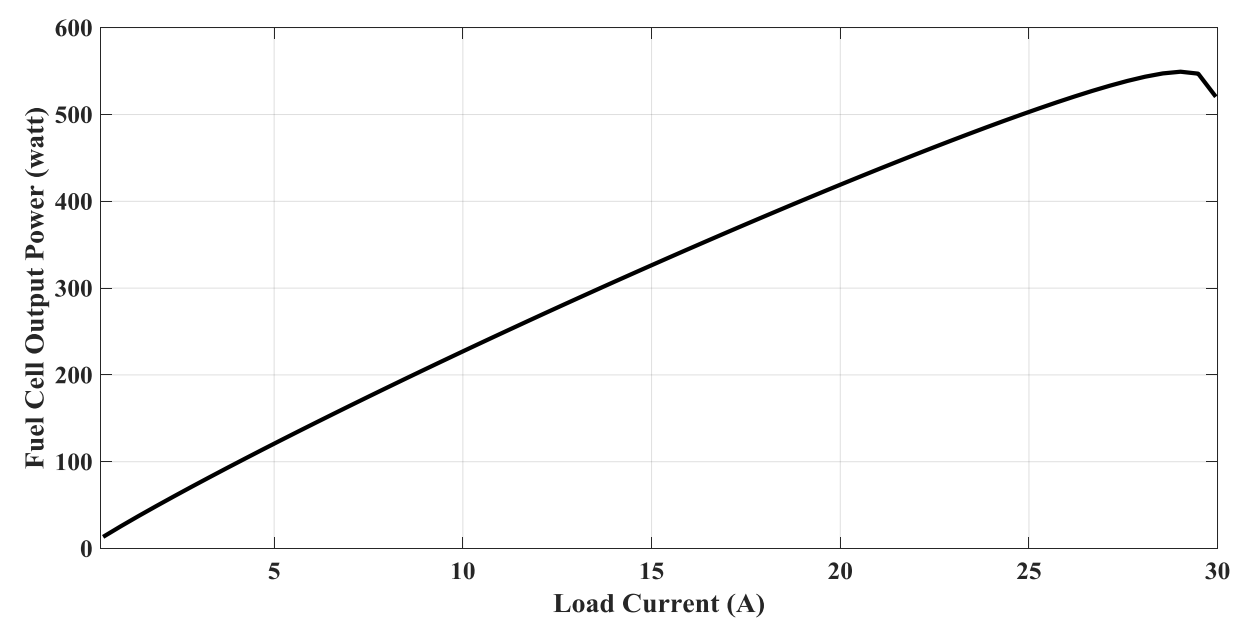

(b)

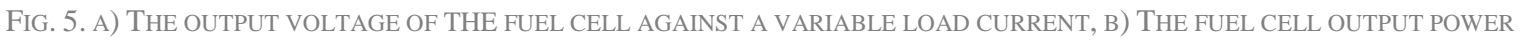
AGAINST A VARIABLE CURRENT.

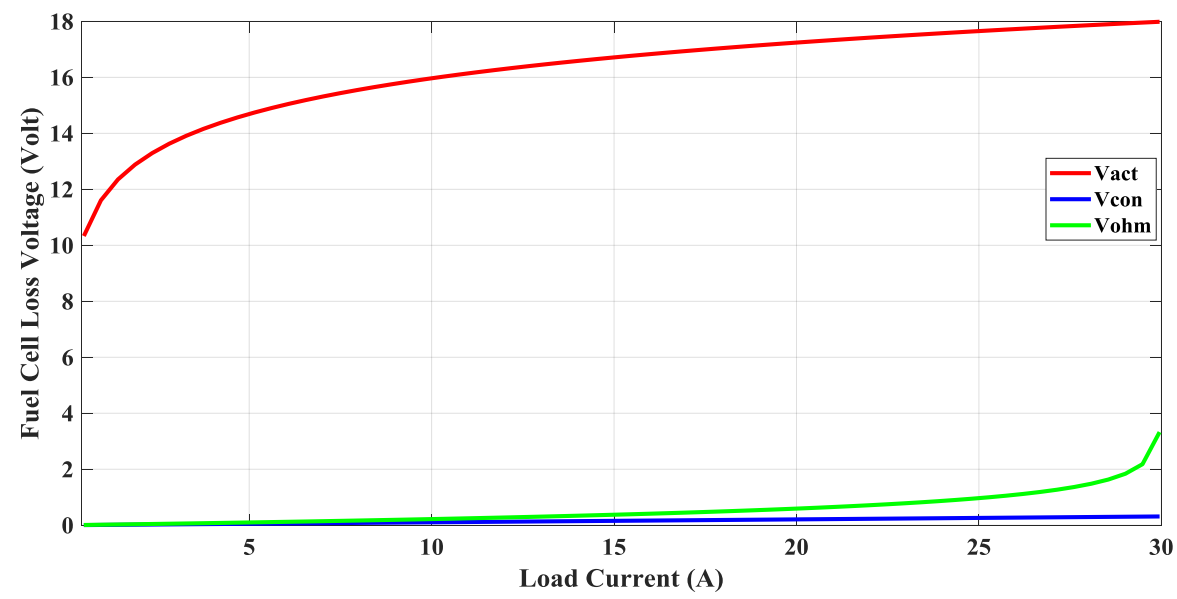

FIG. 6. THE DROP VOLTAGE IN THE FUEL CELL SYSTEM AGAINST THE VARIABLE LOAD CURRENT.

The second study is to show the effect of the hydrogen partial pressure, which changes from 0.1 bar to 5 bar on the output voltage of the Fuel Cell (FC) operation during changing 
the load current of (FC) form 0 A to $30 \mathrm{~A}$, while the temperature of the operation is constant at $25 \mathrm{C}^{\circ}$. Fig 7 shows the output voltage of (FC), which increases when the hydrogen partial pressure increases too, because the thermodynamic potential (EN) value of the PEMFC system, indicated in equation (6), has been improved toward increasing, which led to improving the performance of the Fuel Cell system.

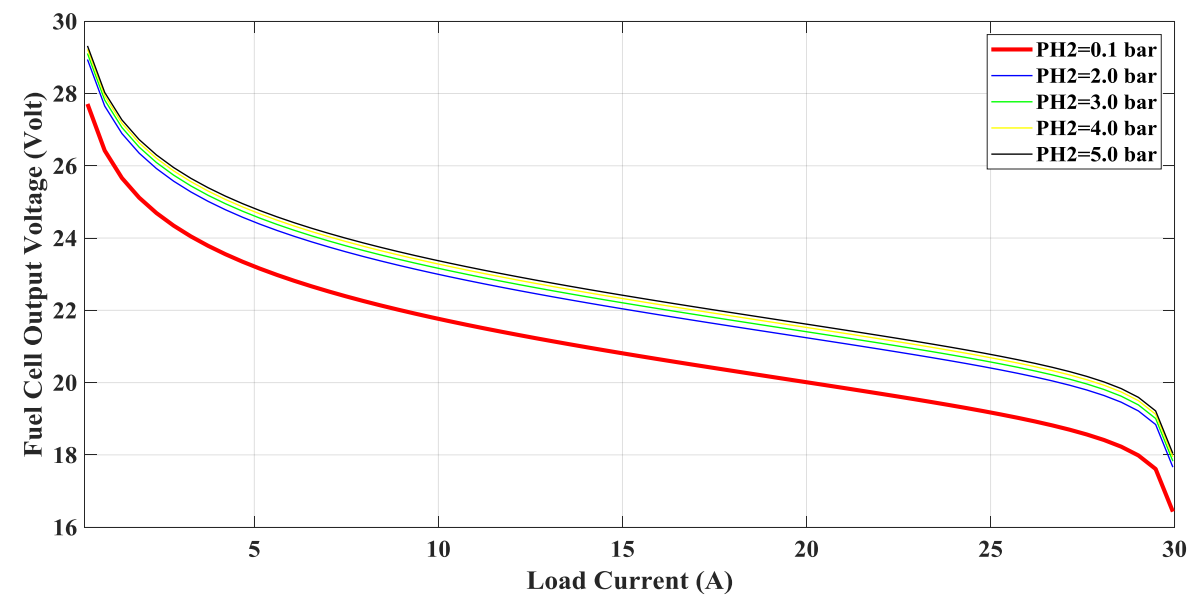

FIG. 7. THE FUEL CELL OUTPUT VOLTAGE SYSTEM AGAINST LOAD VARIABLE CURRENT WHEN THE HYDROGEN PARTIAL PRESSURE IS CHANGED AGAINST VARIABLE LOAD CURRENT.

The third study is to show the effect of the temperature which changes from $25 \mathrm{C}^{0}$ to 80 $\mathrm{C}^{\circ}$ on the output voltage of $(\mathrm{FC})$ operation during changing the load current of (FC) from 0 A to $30 \mathrm{~A}$, but the hydrogen partial pressure is kept as a constant value at 1.0 bar and the oxygen partial pressure is kept as a constant value at 0.2 bar. Fig 8 shows the output voltage of (FC), which increases when the temperature increases too, because the thermodynamic potential (EN) value of the PEMFC system has been improved toward increasing, which reduces the impact values of the parameters on the loss voltage in the fuel cell system, and this led to improve the performance of the fuel cell system. However, increasing the temperature of the fuel cell operation will cause a loss of the necessary humidity for the cell membranes, which leads to a negative impact on the life of the fuel cell.

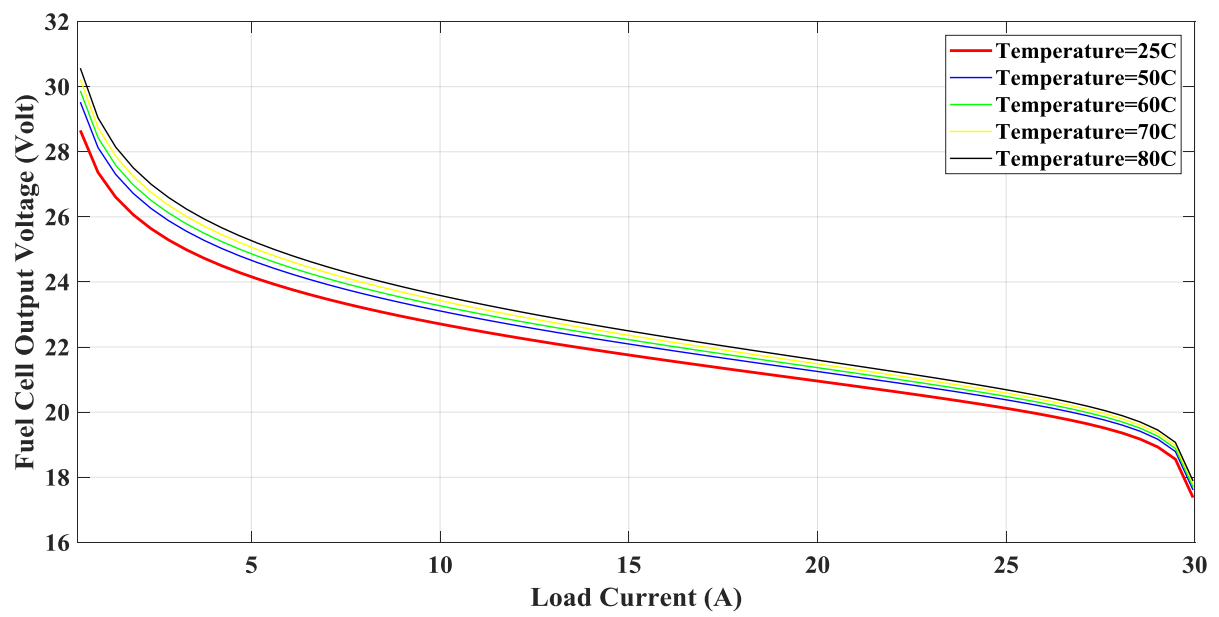

Fig. 8. THE FUEL CELL OUTPUT VOLTAGE WHEN THE OPERATION TEMPERATURE IS CHANGED AGAINST A VARIABLE LOAD CURRENT. 
To establish the proposed controller design, there are two stages that should be achieved as follows:

The first stage is to construct the nonlinear PID neural network PEMFC model using the multi-layer recurrent neural networks structure, as explained in Fig. 3, to develop the PEMFC model system. In stage two, the on-line CPSO algorithm is used to tune the predictive nonlinear PID neural network.

When $\alpha$ and $\beta$ are equal to zero and the linear activation function is used, the general equation of the linear PID neural network becomes:

$$
P H_{2}(k)=k p \times e(k)+k i \times(e(k)+e(k-1))+k d \times(e(k)-e(k-1))
$$

The equation above is called the linear PID neural network.

The on-line CPSO algorithm is used to tune the weights of the predictive (linear and nonlinear) PID neural network, and Table II shows the parameters of the on-line CPSO:

TABLE II. PARAMETERS OF THE ON-Line CPSO ALGORITHM.

\begin{tabular}{cccccccc}
\hline Type of Controller & $\begin{array}{c}\text { Number of } \\
\text { Particles }\end{array}$ & $\begin{array}{c}\text { Particle's } \\
\text { weights }\end{array}$ & $\begin{array}{c}\text { Max. } \\
\text { inertia } \\
\text { weight } \\
\text { Wmax }\end{array}$ & $\begin{array}{c}\text { Min. } \\
\text { inertia } \\
\text { weight } \\
\text { Wmin }\end{array}$ & c $_{1}$ and $c_{2}$ & $\mathrm{r}_{1}$ and $\mathrm{r}_{2}$ & $\begin{array}{c}\text { The best } \\
\text { number of } \\
\text { iterations }\end{array}$ \\
\hline Nonlinear PID NN & 20 & 4 & 0.7 & 0.3 & 1.496 & $\begin{array}{c}\text { Random } \\
(0,1)\end{array}$ & 50 \\
\hline Linear PIDNN & 20 & 3 & 0.7 & 0.3 & 1.496 & $\begin{array}{c}\text { Random } \\
(0,1)\end{array}$ & 50 \\
\hline
\end{tabular}

In 125 samples, the desired output voltage required for the PEMFC system is changed in five phases with the load current, which also changes in five stages of $(15,10,6,15$ and $10 \mathrm{~A})$, as shown in Fig. 9. Fig 10 shows the one step ahead for the predictive linear and nonlinear PID neural network, where in the linear one, the error is not equal to zero due to the small oscillation in the output without an overshoot in the transient state, as shown in Fig. 10. The performance of the nonlinear PIDNN controller was a clear response in terms of the excellent tracking error of the actual output voltage to the desired output voltage at the different step changes without oscillation when compared with the linear PIDNN controller, as shown in Fig. 10. Table III shows the dynamic characteristics for the Linear and Nonlinear PID Neural Network controllers during only the first step change. From this table, we can observe that the nonlinear PIDNN controller has a faster response in the tracking error compared to the linear PIDNN controller in terms of the rise time and the settling time

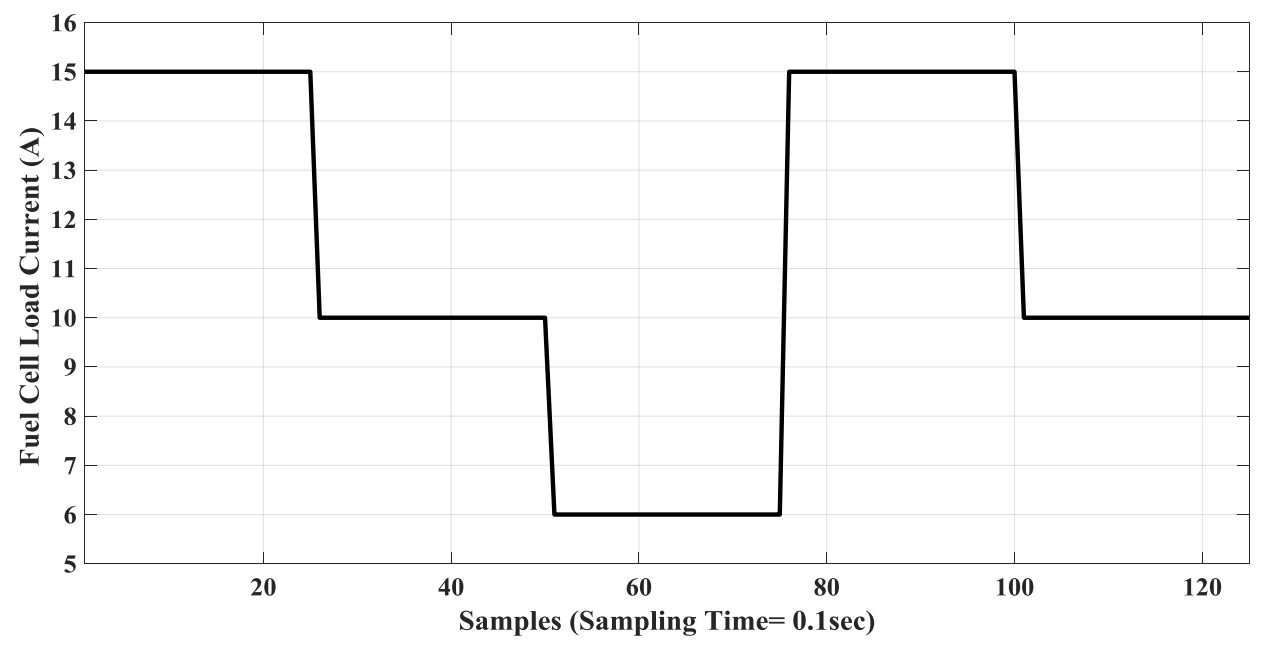

Fig. 9. CURRENT VARIATION OF THE FC LOAD.

Received 8 May 2019; Accepted 5 September 2019 


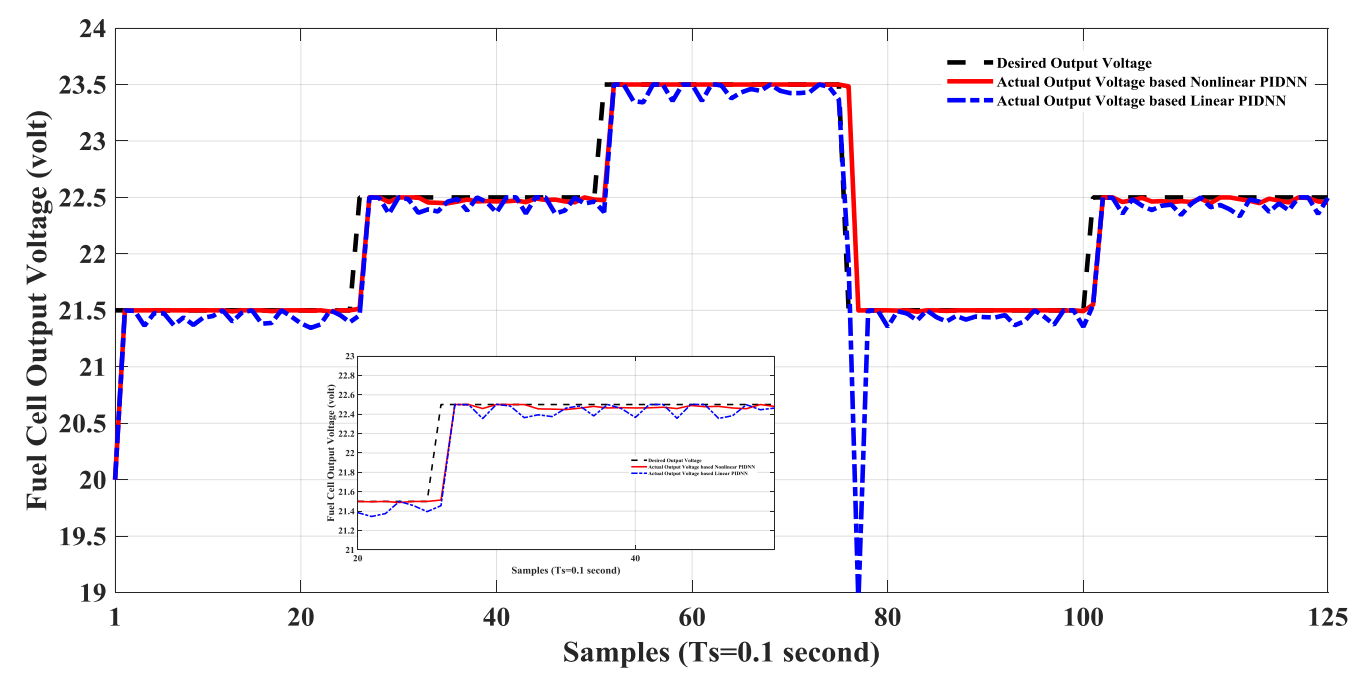

Fig. 10. The Fuel actual outPut VOLTAGE of PEM FuEL CELl FOR ONE-STEP PREDICTIVE PID NEURAL NETWORK.

TABLE III. STEP RESPONSE CHARACTERISTICS OF THE LINEAR AND NONLINEAR PIDNN CONTROLLER.

\begin{tabular}{ccccc}
\hline Type of Controller & Rise time & Settling time & Overshoot & Peak time \\
\hline Nonlinear PID NN & 0.0957 & 0.11 & 0 & 0.121 \\
\hline Linear PIDNN & 0.0998 & 0.149 & 0 & 0.127
\end{tabular}

In the predictive linear PID neural network controller, for one step ahead, the control action response $\left(\mathrm{PH}_{2}\right)$ is clearly not smooth for tracking the desired output voltage, as shown in Fig. 11. While in the nonlinear PIDNN controller, the control action has a smooth response and it was able to track the desired output voltage and minimize the steady state error, as shown in Fig. 11.

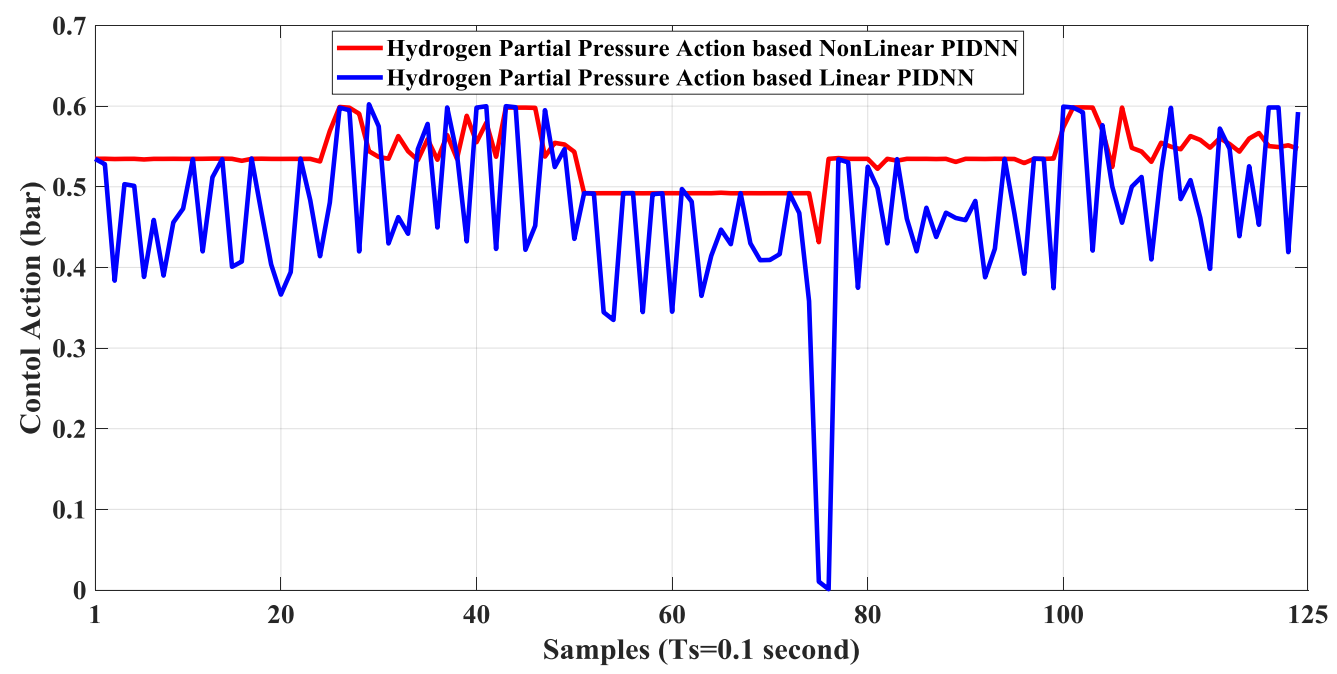

FIG. 11. THE FUEL CONTROL ACTION FOR ONE STEP AHEAD FOR THE LINEAR AND NONLINEAR PID NEURAL NETWORK.

Based on the CPSO, the on-line performance of the mean square error of the predictive linear PIDNN controller for one step ahead is shown in Fig. 12, where the minimum value of the performance index reaches to 0.053 . On the other hand, the on-line performance of the mean square error of the nonlinear PIDNN controller for one-step ahead is equal to 0.0305 . 


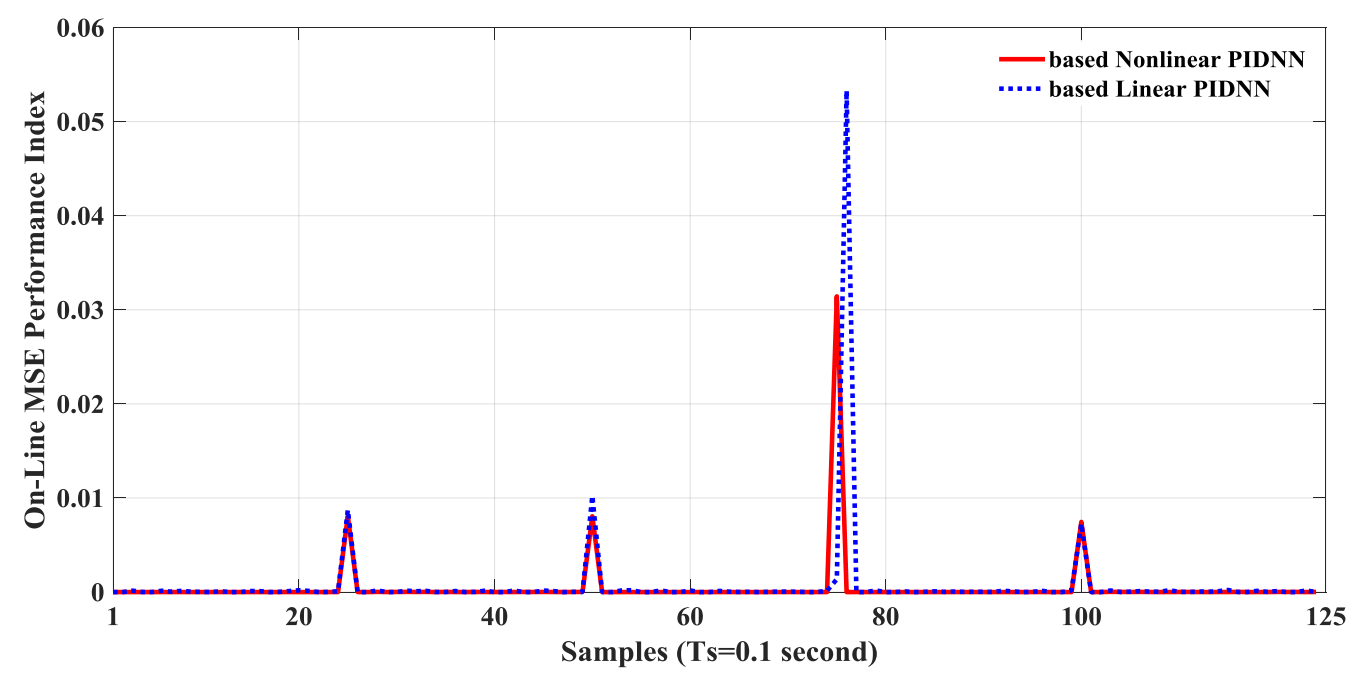

FIg. 12. THE VALUE OF THE ON-LINE OBJECTIVE COST FUNCTION FOR ONE STEP AHEAD PREDICTIVE LINEAR AND NONLINEAR PID NEURAL NETWORK.

\section{CONCLUSION}

The numerical simulation results of the suggested predictive nonlinear PIDNN controller with the CPSO algorithm for controlling the nonlinear PEMFC system are presented in this paper. The proposed nonlinear PIDNN controller compared to the linear PIDNN controller has many abilities in terms of: (i) Strong adaptation for the controller parameters without the over-learning problem because the on-line CPSO algprithm was used; (ii) Fast and smooth tuning algorithm which leads to no oscillation in the model output; (iii) High robustness behavior for the predictive nonlinear PIDNN controller when generating the hydrogen partial action to follow the desired output voltage of the PEMFC system during the load current variations.

\section{REFERENCES}

[1] C. Ziogou, S. Voutetakis, M. C. Georgiadis, and S. Papadopoulou, "Model Predictive Control (MPC) Strategies for PEM Fuel Cell Systems - A Comparative Experimental Demonstration,” Chemical Engineering Research and Design, vol. 131, pp. 656-670, March 2018.

[2] W. Daud, R. Rosli, E. Majlan, S. Hamid, and R. Mohamed, "PEM fuel cell system control: A review," Renewable Energy, vol. 113, pp. 620-638, 1 Dec 2017.

[3] X. Wang, W. Yan, Y. Duan, F. Weng, G. Jung, and C. Lee, "Numerical study on channel size effect for proton exchange membrane fuel cell with serpentine flow field," Energy Conversion and Management, vol. 51, pp. 959-968, 2010.

[4] T. Jahnke, G. Futter, A. Latz, T. Malkow, G. Papakonstantinou, G. Tsotridis, P. Schott, M. Gerard, M. Quinaud, M. Quiroga, A.A. Franco, K. Malek, F. Calle-Vallejo, R. Ferreira de Morais, T. Kerber, P. Sautet, D. Lofferda, S. Strahl, M. Serra, P. Polverino, C. Pianese, M. Mayur, W.G. Bessler, and C. Kompis, "Performance and degradation of Proton Exchange Membrane Fuel Cell: State of the art in modeling from atomistic to system scale,” Journal of Power Sources, vol. 304, pp. 207-233, 2016.

[5] J. O. Schumacher, P. Gemmar, M. Denne, M. Zedda, and M. Stueber, "Control of miniature proton exchange membrane fuel cells based on fuzzy logic,” Journal of Power Sources, vol. 129, pp. 143-151, 2004.

[6] O. Turgut, and M. Coban, "Optimal proton exchange membrane fuel cell modeling based on hybrid Teaching Learning Based Optimization-Differential Evolution algorithm,” Ain Shams Engineering Journal, vol. 7, pp. 347-360, March 2016.

[7] P. Thounthong, S. RaEl, and B. Davat, "Control Algorithm of Fuel Cell and Batteries for Distributed Generation System," IEEE Transactions on Energy Conversion. , pp. 148-155, March 2008.

[8] A. Abbaspour, A. Khalilnejad, and Z. Chen, "Robust adaptive neural network control for PEM fuel cell," International Journal of Hydrogen Energy, vol. 41, pp. 20385-20395, 26 November 2016. 
[9] A. Kheirandish, N. Shafiabady, M. Dahari, M. Kazami, and D. Isa, "Modeling of commercial proton exchange membrane fuel cell using support vector machine," International Journal of Hydrogen Energy, vol. 41, pp. 11351-11358, 13 July 2016.

[10] M. Derbeli, M. Farhat, O. Barambones, and L. Sbita, "Control of PEM fuel cell power system using sliding mode and super-twisting algorithms,” International Journal of Hydrogen Energy, vol. 42, pp. 8833-8844, 30 March 2017.

[11] K. Chang, "The optimal design for PEMFC modeling based on Taguchi method and genetic algorithm neural network," International Journal of Hydrogen Energy, vol. 36, pp. 13683-13694, October 2011.

[12] A. Askarzadeh, and L. Coelho, "A backtracking search algorithm combined with Burger's chaotic map for parameter estimation of PEMFC electrochemical model,” International Journal of Hydrogen Energy, vol. 39, pp. 11165- 11174, 15 July 2014.

[13] I. Matraji, S. Laghrouche, S. Jemei, and M. Wack, "Robust control of the PEM fuel cell air-feed system via sub-optimal second order sliding mode,” Applied Energy, vol. 104, pp. 945-957, April 2013.

[14] A.A. El-Fergany, "Extracting optimal parameters of PEM fuel cells using Salp Swarm Optimizer," Renewable Energy, vol. 119, pp. 641-648, April 2018.

[15] Q. Li, W. Chen, Z. Liu, A. Guo, and J. Huang, "Nonlinear multivariable modeling of locomotive proton exchange membrane fuel cell system," International Journal of Hydrogen Energy, vol. 39, pp. 13777-13786, 22 August 2014.

[16] S. Ebrahimi, B. Ghorbani, and K. Vijayaraghavan, "Optimization of catalyst distribution along PEMFC channel through a numerical two-phase model and genetic algorithm,” Renewable Energy, vol. 113, pp. 846-845, December 2017.

[17] S. Yang, and N. Wang, "A novel P system based optimization algorithm for parameter estimation of proton exchange membrane fuel cell model,” International Journal of Hydrogen Energy, vol. 37, pp. 8465-8476, May 2012.

[18] M. Ali, M.A. El-Hameed, and M.A. Farahat, "Effective parameter's identification for polymer electrolyte membrane fuel cell models using grey wolf optimizer," Renewable Energy, vol. 111, pp. 455-462, October 2017.

[19] J. Liua , W. Linc , F.Alsaadid, and T.Hayatd, “Nonlinear Observer Design for PEM Fuel Cell Power Systems Via Second Order Sliding Mode Technique,” Neurocomputing, vol. 168, pp. 145-151, November 2015.

[20] C. Ziogoua, S.Papadopouloua, M. Georgiadis, and S. Voutetakis, "On-Line Nonlinear Model Predictive Control of A PEM Fuel Cell System,” Journal of Process Control, vol. 23, pp. 483-492, 2013.

[21] A. Al-Araji, "A Comparative Study of Various Intelligent Algorithms Based Nonlinear PID Neural Trajectory Tracking Controller for the Differential Wheeled Mobile Robot Model”. Journal of Engineering, vol. 20, No. 5, pp. 44-60, 2014.

[22] A. Al-Araji, “A Cognitive PID Neural Controller Design for Mobile Robot Based on Slice Genetic Algorithm”. Engineering \& Technology Journal. Vol. 33, No. 1, pp. 208-222, 2015.

[23] K. A. Dagher, A. S. Al-Araji, "Design of an Adaptive PID Neural Controller for Continuous Stirred Tank Reactor based on Particle Swarm Optimization”. Al-Khwarizmi Engineering Journal, vol. 9, No. 4, pp. 46-53, 2013

[24] K. E. Dagher, "Design of an Adaptive Neural Voltage-Tracking Controller for Nonlinear Proton Exchange Membrane Fuel Cell System based on Optimization Algorithms". Journal of Engineering and Applied Sciences. vol. 13, No. 15, pp. 6188-6198, 2018. 